\section{Case Reports in Neurology}

Case Rep Neurol 2021;13:50-52

DOI: $10.1159 / 000512266$

Published online: January 28, 2021

(C) 2021 The Author(s)

Published by S. Karger AG, Basel

www.karger.com/crn

This article is licensed under the Creative Commons Attribution-NonCommercial 4.0 International License (CC BY-NC) (http://www.karger.com/Services/OpenAccessLicense).

Usage and distribution for commercial purposes requires written permission.

\title{
Hemichorea Neglect after Stroke
}

\author{
Yosuke Aiba Ryuji Sakakibara Tsuyoshi Ogata Fuyuki Tateno \\ Neurology, Internal Medicine, Sakura Medical Center, Toho University, Sakura, Japan
}

\section{Keywords}

Neglect $\cdot$ Hemichorea $\cdot$ Striatum $\cdot$ Stroke

\begin{abstract}
We report a case of a 74-year-old Japanese woman who, after left thalamic infarction, developed right hemichorea and its neglect. This rare finding was associated with ipsiand contralateral brain perfusion changes, presumably reflecting de-afferentiation within the brain.

(c) 2021 The Author(s)

Published by S. Karger AG, Basel
\end{abstract}

\section{Introduction}

As compared with parkinsonian bradykinesia, chorea is sometimes not bothersome or even not noticed by the patients, albeit cognitive status is preserved [1]. We recently had a case of an elderly woman who, after left thalamic infarction, presented with right hemichorea and its neglect.

\section{Case Report}

We had a 74-year-old Japanese woman with hypertension that was cared for by a local physician. She was referred because of a sudden onset of right hemichorea, but without right hemiplegia. Her families reported that her cognitive status (Mini-Mental State Examination [MMSE] score of 22/30, Frontal Assessment Battery score of 13/18) did not change. She could manage herself in terms of meals, clothes, and communication with other persons. In contrast, she neglected and even denied her hemichorea. 3T MRI showed a small lesion in the left striatum that was high-signal in T2-weighted image and diffusion-weighted image (Fig. 1a). MR angiography was normal. ECD-brain perfusion SPECT showed a statistically significant hyperperfusion in the left paracentral lobule, and significant hypo-perfusion in the left anterior cingulate cortex (Fig. 1b). Her hemichorea persisted for the following 12 months with gradual improvement of severity. During this period, she still showed neglect of her hemichorea.

\begin{tabular}{ll}
\hline & Ryuji Sakakibara \\
Neurology, Internal Medicine \\
Sakura Medical Center, Toho University \\
$564-1$ Shimoshizu, Sakura 285-8741 (Japan) \\
sakakibara@sakura.med.toho-u.ac.jp
\end{tabular}




\section{Case Reports in Neurology}

Case Rep Neurol 2021;13:50-52

\begin{tabular}{l|l}
\hline DOI: 10.1159/000512266 & $\odot 2021$ The Author(s). Published by S. Karger AG, Basel
\end{tabular} www.karger.com/crn

Aiba et al.: Hemichorea Neglect after Stroke

\section{Discussion}

Neglect of hemichorea seems rare. To the extent possible, this is the first such case report. As compared with parkinsonian bradykinesia, chorea is sometimes not bothersome or even not noticed by the patients, albeit cognitive status is preserved [1]. Our patient had MMSE score of 22/30; therefore, her neglect cannot be attributed to her cognitive decline. Recently, de-afferentiation within the brain is regarded as one of putative mechanisms for hemispatial neglect [2]. In our patient, ECD-brain perfusion SPECT revealed statistically significant hyperperfusion in the left paracentral lobule (ipsilateral to the thalamic lesion), while there was hypo-perfusion in the left anterior cingulate cortex (contralateral to the thalamic lesion). These findings might reflect de-afferentiation of the left thalamus within the brain, which can underlie neglect of hemichorea as observed in our patient.

In conclusion, we report a case of an elderly woman who, after left thalamic infarction, developed right hemichorea and its neglect. This rare finding was associated with ipsi- and contralateral brain perfusion changes, presumably reflecting de-afferentiation within the brain.

\section{Statement of Ethics}

The subject has given her written informed consent to publish her case (including publication of images). This study concept was in accordance with the declaration of Helsinki principles, and was approved by the local Ethics Committee.

\section{Conflict of Interest Statement}

We have no conflict of interest or disclosure to be reported.

\section{Funding Sources}

No targeted funding reported.

\section{Author Contributions}

Y. Aiba participated in the acquisition of data. T. Ogata participated in the acquisition, analysis and interpretation of data. R. Sakakibara participated in the study concept and design, acquisition of data, analysis and interpretation of data, and preparation of the manuscript. F. Tateno participated in the acquisition of data.

\section{References}

1 Sitek EJ, Sołtan W, Wieczorek D, Schinwelski M, Robowski P, Reilmann R, et al. Self-awareness of motor dysfunction in patients with Huntington's disease in comparison to Parkinson's disease and cervical dystonia. J Int Neuropsychol Soc. 2011 Sep;17(5):788-95.

2 Heilman KM. Possible mechanisms of anosognosia of hemiplegia. Cortex. 2014 Dec;61:30-42.

\section{Karger'=}


Case Reports in Neurology
Case Rep Neurol 2021;13:50-52

DOI: $10.1159 / 000512266$

(c) 2021 The Author(s). Published by S. Karger AG, Basel www.karger.com/crn

Aiba et al.: Hemichorea Neglect after Stroke
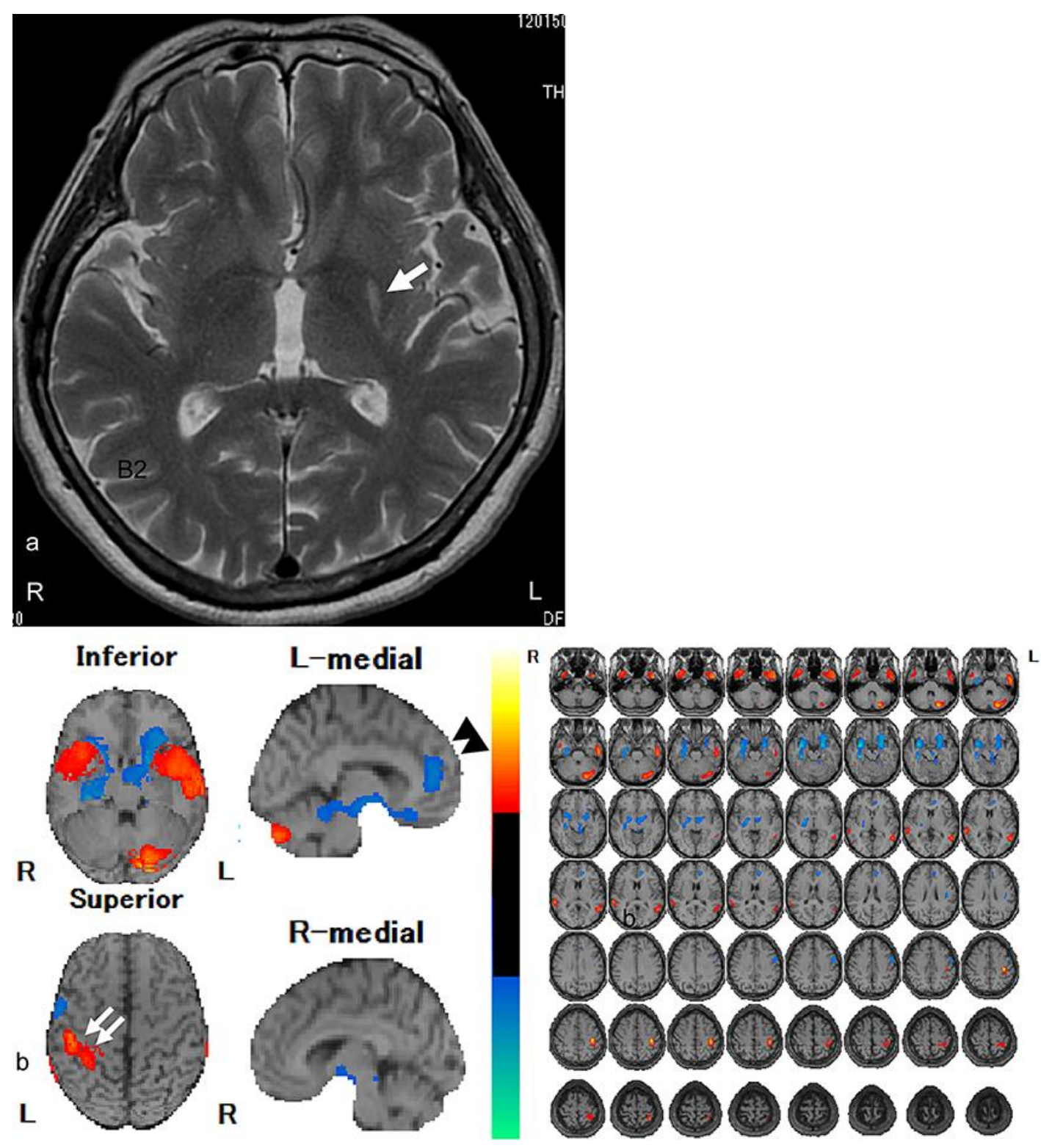

Fig. 1. Imaging of the patient. a 3T MRI showed a small lesion in the left striatum that was high-signal in T2-weighted image (arrow). b ECD-brain perfusion SPECT showed a statistically significant hyper-perfusion in the left paracentral lobule (arrows), and significant hypo-perfusion in the left anterior cingulate cortex (arrowheads). 